\title{
Manajemen dan Mutu Pembelajaran Bahasa Indonesia di SMP Negeri 4 Rejang Lebong
}

\author{
Murni Yanto \\ Sekolah Tinggi Agama Islam Negeri (STAIN) Curup \\ murni_yanto@79yahoo.com
}

\begin{abstract}
Management and quality of learning is very important in the effort to realize education. Effective learning quality management will be able to influence between teacher as facilitator and learner as subject in teaching learning. This research is to know the management and quality of learning Indonesian at State Junior High School 4 Rejang Lebong. In particular this study to describe: 1). How to manage learning planning in Indonesian language, 2). How to manage the implementation of Indonesian language learning, 3). How to evaluate Indonesian learning management, 4). How innovation is done in the management of learning Indonesian language. The method used is descriptive qualitative. Methods of data collection are interviews, observation and documentation. The quality of the study of quality management of Indonesian language learning, can be concluded to contribute to learning Indonesian language. The implication of this finding is that Indonesian teachers can understand quality management in applying learning.
\end{abstract}

Keywords : Management, Quality, Learning Indonesian

\begin{abstract}
Abstrak: Manajemen dan mutu pembelajaran sangat penting dalam upaya mewujudkan pendidikan. Manajemen mutu pembelajaran yang efektif akan mampu mempengarubi antara guru sebagai pasilitator dengan peserta didik sebagai subjek dalam belajar mengajar. Penelitian ini adalab untuk mengetabui manajemen dan mutu pembelajaran bahasa Indonesia di Sekolah Menengab Pertama Negeri 4 Rejang Lebong. Secara khusus penelitian ini untuk mendeskripsikan : 1). Bagaimana manajemen perencanaan pembelajaran bahasa Indonesia, 2). Bagaimana manajemen pelaksanaan pembelajaran bahasa Indonesia, 3). Bagaimana evaluasi manajemen pembelajaran bahasa Indonesia, 4). Bagaimana inovasi yang dilakukan dalam manajemen pembelajaran bahasa Indonesia. Metode yang digunakan adalab diskriptif kualitatif. Metode pengumpulan data adalah wawancara, observasi dan dokumentasi. Kualitas studi manajemen mutu pembelajaran bahasa Indonesia, disimpulkean dapat memberikan kontribusi terhadap pembelajaran bahasa Indonesia. Implikasi dari temuan ini adalah agar guru bahasa Indonesia dapat memahami manajemen mutu dalam menerapkan pembelajaran.
\end{abstract}

Kata Kunci : Manajemen, Mutu, Pembelajaran bahasa Indonesia

\section{Pendahuluan}

Dalam proses belajar mengajar masih dijumpai bahwa siswa mengalami kesulitan belajar khususnya dalam belajar bahasa Indonesia. Kenyatan inilah yang harus ditangani dan dipecahkan. Kesulitan belajar merupakan suatu kondisi alam proses belajar mengajar ditandai dengan hambatan-hambatan tertentu dalam mencapai hasil belajar yang diharapkan. Kesulitan belajar siswa dapat disebabkan oleh beberapa faktor, baik faktor internal maupaun faktor eksternal seperti: fisilogi, faktor sosial. Selain itu, terdapat pula kesulitan dalam belajar bahasa Indonesia seperti: (1) kesulitan dalam mencerna bacaan. Dalam hal ini dipandang siswa yang telah memperoleh pengajaran membaca dan mencernanya, tetapi belum mengusai mungkin karena siswa itu sendiri yang kurang memahami dan kurang mengusainya. (2) 
kesulitan belajar dan menggunakan prinsip, kita analisa tampaklah bahwa pada umumnya sebab kesullitan tersebut antara lain:(a) siswa tidak menggunakan prinsip yang digunakan untuk mengembangkan butir pengetahuan yang perlu di mengerti. (b) miskin minat baca secara pontesial merupakan kesulitan belajar. Prinsip yang diajarkan konstektual (contoh nyata). (c) siswa kurang jelas dalam prinsip yang telah diajarkan.(d) kesulitan memecahkan soal bentuk wacana/cerita.

Menurut Lubis ( 1993:21) wacana adalah kesatuan dari beberapa kalimat yang satu dengan lain saling terkait. Dalam hal ini wacana memahami teks bacaan dalam kalimat. Menurut Hendry Guntur Tarigan ( 2009:22 ) wacana adalah rentangan ujaran yang berkesinambungan ( urutan kalimatkalimat individual.

Sedangkan Baryadi ( 2000:17 )mengemukakan bahwa untuk menciptakan keutuhan, bagian wacana harus selalu berhubungan sejalan dengan pandangan bahwa bahasa itu sendiri berbentuk dan bermakna.

Memecahkan soal bentuk wacana/cerita berarti menerapkan pengetahuan yang dimiiki secara teoritis untuk memecahkan persoalan nyata dan keadaan Sehari-hari. keberhasilan dalam memecahkan persoalan terbentuk wacana / cerita tergantung kemampuan pemahaman wacana, yaitu kemampuan memahami soal berbentuk wacana/bercerita dan kemampuan untuk mencari gagasan utama/pokok pikirannya. Biasanya siswa kesulitan dalam memecahkan soal yang berbentuk wacana/cerita untuk mencari gagasan utamanya. Adapun kemampuan yang harus dikembangkan dalam diri siswa melalui pembelajaran bahasa Indonesia antara lain: kemampuan untuk mendengar, membaca, menulis, dan berbicara dan implementasikannya dalam pembiasaan sehari-hari. Selain itu juga pembelajaran bahasa Indonesia juga berfungsi untuk mengembangkan kemampuan mengkonsumsikan gagasan dengan bahasa melalui metode membaca, cerita, menulis dan berbicara. Menurut Chaer ( 2011:30 ) menyatakan: bahasa adalah sistem lambang bunyi di gunakan oleh sekelompok anggota masyarakat untuk beraksi dan mengidentifikasi diri. Sistem bahasa merupakan sistem lambang sama dengan sistem lambang lalu lintas atau sistem lambang lainnya. Dalam pengelolaan pembelajaran bahasa, siswa merupakan hasil dari suatu interaksi tindakantindakan mengajar yaitu membelajarkan siswa. Guru sebagai pendidik melakukan pelaksanaan pembelajaran berdasarkan kurikulum yang berlaku. Dalam teori tersebut guru menggunakan teori pendidikan . guru membuat desain instruksional (RPP), kemudian megacu pada desain tersebut menyusun program pembelajaran di rumah dan bertanggung jawab atas jadwal belajar yang di buat. Sementara itu siswa sebagai pembelajar atau perserta didik di sekolah memiliki kepribadian pengalaman (daya serap) dan tujuan siswa tersebut mengalami perkembangan jiwa yang sesuai dengan dirinya menuju 
kebutuhan dan kemandirian. Pengelolaan pembelajaran adalah kegiatan guru secara terprogram dalam mendesain instruksional, untuk membuat siswa belajar mengajar di kelas, yang menekankan pada penyedian sumber belajar siswa-siswa di kelas.

Manajemen pembelajaran adalah kegiatan guru secara terprogram dalam mendesain instruksional, untuk membuat siswa belajar mengajar di kelas, yang mana menekankan pada penyediaan sumber belajar siswa di kelas. Dalam pembelajaran guru harus memahami hakekat materi pelajaran sebagai suatu pengajaran yang dapat mengembangkan kemampuan yang dapat merangsang siswa untuk belajar dengan perecanaan pembelajaran yang matang oleh guru.

Dalam pembelajaran guru harus memahami hakekat materi sebagai suatu pelajaran yang dapat mengembangkan kemampuan siswa untuk belajar dengan perencanaan pembelajaran yang matang oleh guru. Bruner (1960:20) mengatakan bahwa perlu adanya teori pembelajaran yang akan menjelaskan azas-azas untuk merancang pembelajaran yang efektif di kelas. Menurut pandangan bruner, teori belajar bersifat diskriptif, sedangkan pembelajaran itu bersifat preskriftif.

Menurut Stevick dalam Mansoer Pateda (1991:38) tugas guru bahasa meliputi tiga hal. Ketiga tugas itu adalah (1) mengembangkan potensi komunikasi, (2) mengembangkan potensi linguistik, dan (3) mengembangkan potensi personal.

Upaya untuk meningkatkan mutu pembelajaran sekolah seperti dapat menggunakan yang disarankan oleh Sudarwan Danim ( 2007:56) yaitu dengan melibatkan lima faktor yang dominan : (1). Kepemimpinan Kepala sekolah; kepala sekolah harus memiliki dan memahami visi kerja secara jelas, mampu dan mau bekerja keras, mempunyai dorongan kerja yang tinggi, tekun dan tabah dalam bekerja, memberikanlayananyang optimal, dan disiplin kerja yang kuat. (2). Siswa; pendekatan yang harus dilakukan adalah "anak sebagai pusat " sehingga kompetensi dan kemampuan siswa dapat digali sehingga sekolah dapat menginventarisir kekuatan yang ada pada siswa . (3). Guru; pelibatan guru secara maksimal, dengan meningkatkan kopentensi dan profesi kerja guru dalam kegiatan seminar, MGMP, lokakarya serta pelatihan sehingga hasil dari kegiatan tersebut diterapkan disekolah. (4). Kurikulum; adanya kurikulum yang tetap tetapi dinamis, dapat memungkinkan dan memudahkan standar mutu yang diharapkan sehingga goals (tujuan) dapat dicapai secara maksimal; (5). Jaringan Kerjasama; jaringan kerjasama tidak hanya terbatas pada lingkungan sekolah dan masyarakat semata (orang tua dan masyarakat) tetapi dengan organisasi lain, seperti perusahaan / instansi sehingga output dari sekolah dapat terserap didalam dunia kerja. 
Berdasarkan uraian di atas pembelajaran dengan pendekatan kompetensi dapat dilakukan dengan langkah-langkah umum sebagai berikut: (a) tahap manajemen perencanaan pembelajaran. Dalam tahap manajemen perecanaan pertama-tama perlu ditetapkan kompentesi -kompentesi yang akan mengwujudkan dalam kegiatan pembelajaran. Berdasarkan kompentesikompentesi tersebut selanjutnya dikembangkan tema, subtema, dan topiktopik mata pelajaran yang diajarkan. Pendekatan kompentesi yang mendasar konsep kesepadanan antara teori praktek sering menggunakan modul sebagai sistem pembelajaran. Modul merupakan suatu unik yang lengkap terdiri atas suatu rangkaian belajar yang di susun untuk membantu peserta didik untuk mencapai sejumlah tujuan yang dirumuskan secara jelas. (b) tahap pelaksanaan manajemen pembelajaran. Pelaksanaan pembelajaran merupakan langkah merealisasikan konsep pembelajaran dalam bentuk perbuatan. Dalam pendidikan berdasarkan kompetensi pelaksanaan pembelajaran merupakan suatu rangkaian pembelajaran yang dilakukan secara berkesinambungan yang meliputi tahap persiapan, penyajian, dan peniliaian. Tahap penyajian merupakan tahap guru menyajikan informasi, menjelaskan cara kerja baik keseluruhan proses masing-masing gerakan yang dilakukan dengan cara demontrasi. Tahap aplikasi atau praktek perserta didik kesempatan melakukan sendiri kegiatan belajar yang ditugaskan kegiatan guru lebih terkonsentrasi kepada pengawas dan pemberian bantuan pada perorangan atau kelompok. Tahap penilaian adalah tahap guru memeriksa hasil kerja dengan menyertakan peserta didik untuk penilaian kualitas kerja serta waktu belajar yang dipergunakan dalam menyelesaikan pekerjaan tersebut. (c) tahap evaluasi. Salah satu kegiatan yang ikut menentukan keberhasilan proses belajar mengajar (PBM) ialah penilaian yang baik menyangkut program, kegiatan, dan hasil proses belajar mengajar. Lingkup kegiatan ini sangat luas karena itu di dalam hal ini di pusatkan perhatian penilaian pelajaran membaca. Dengan adanya penilaian pelajaran membaca siswa dapat mencerna soal-soal yang berbentuk cerita dan siswa bisa mencari gagasan utama/pikiran utama dalam suatu bacaan.

\section{Pembahasan}

1. Manajemen perencanaan pembelajaran bahasa Indonesia

Manajemen telah banyak diulas oleh para ahli. Terry yang dikutip oleh Tripathi dan Reddy ( $2008: 2$ ) mendefinisikan manajemen sebagai " $a$ process consisting of planning, organising and controlling, performed to determine and accomplish the objectives by the use of people and resources. Definisi ini menunjukkan bahwa manajemen adalah sebuah proses yang berisi perencanaan, pengorganisasian dan pengawasan yang dilakukan untuk menentukan dan mencapai tujuan dengan menggunakan orang dan sumber daya. Manajemen atau mengelola adalah proses mendesain dan 
mengelola lingkungan yang mana individu bekerja mendesain dan mengelola lingkungan yang mana individu bekerja bersama dalam kelompok secara efektif dalam mencapai tujuan yang telah dipilih. Selanjutnya Gatewood, Taylor dan Ferrel ( 1995:2) menjelaskan bahwa :

"Management is a set of activities designed to achieve an organization's objectives by using its resources effectively and efficiently in a changing environment. Effectively means having the intended result and efficiently means accomplisibing the objectives with a minimum of resource".

Manajemen adalah serangkaian kegiatan yang didesain untuk mencapai tujuan organisasi dengan menggunakan sumber daya secara efisien dan efektif dan dilakukan dalam lingkungan yang senantiasa berubah dari waktu ke waktu. Efektif berarti tercapai tujuan yang ditetapkan dan efisien berarti mencapai tujuan dengan menggunakan sedikit mungkin sumber daya yang tersedia.

Menurut Piaget dalam Mgs. Nazarudin ( 2007:163-164 ) langkahlangkah pembelajaran adalah sebagai berikut : (a) menentukan topik yang dapat dipelajari oleh anak sendiri, (b) menilai dan mengembangkan aktivitas kelas, (c) mengetahui adanya kesempatan bagi guru untuk mengemukakan pertanyaan yang menunjang proses pemecahan masalah,(d) menilai pelaksanaan kegiatan memperhatikan keberhasilan dan melakukan revisi.

Menurut Sudjana ( 2004:49) perencanaan pembelajaran merupakan salah satu fungsi dari manajemen. Guru dalam merencanakan pembelajaran salah satunya dengan membuat silabus. Menurut Nasution ( 1989:67 ) memaknai pembelajaran sebagai upaya mengumpulkan materi. Demi kelangsungan proses pembelajaran maka hendaknya dibuat rencana pembelajaran agar dapat memperoleh hasil yang diharapkan dari proses pembelajaran. Sedangkan menurut Majid (2013:120) Perencanaan adalah menyusun langkah-langkah yang akan dilaksanakan untuk mencapai tujuan yang telah di tentukan. Perencanaan tersebut dapat di susun berdasarkan kebutuhan dalam jangka waktu tertentu sesuai dengan keinginan membuat perencanaan, namun yang lebih utama adalah perencanaan yang dibuat harus di laksanakan dengan mudah dan tepat sasaran. Guru memberikan penjelasan sejelas mungkin dan mengajak siswa untuk aktif dengan cara sesekali melontarkan pertanyaan. Dalam menjelaskan guru memberikan ilustrasi gambar hidup yang diambilkan dari lingkungan siswa. Menurut Khaeruddin dan Mahfud junaidi ( 2007:208 ) Dalam setiap aspek kemahiran guru selalu memberikan penjelasan dengan memberikan ilustrasi gambar. Menurut Hendry Guntur Tarigan ( 1985:149 ) guru ideal mempunyai motivasi kuat dalam hubungannya dengan tujuan memilih profesinya. 
Penjelasan yang diberikan kepada siswa diharapkan dapat meningkatkan kompetensi para siswanya. Manajemen perencanaan mutu pembelajaran merupakan tugas pokok yang harus dibuat dan dijalankan guru sebelum melaksanakan proses pembelajaran. Di dalam menyusun perangkat perencanaan pembelajaran, guru terlebih dahulu harus memahami langkah-langkah pembuatan dan penyusunannya sesuai dengan visi, misi dan tujuan pembelajaran dan mengacu pada kurikulum yang sudah ditetapkan.

Pada setiap aktivitas pembelajaran, manajemen perencanaan merupakan kegiatan yang sangat penting karena tahap ini merupakan landasan dalam pencapaian kesuksesan pembelajaran bahasa Indonesia. Manajemen perencanaan pembelajaran yang matang akan sangat mendukung ketercapaian tujuan umum pembelajaran bahasa Indonesia, hal ini juga berhubungan dengan kemampuan guru bahasa Indonesia dalam menguasai bahasa ajar. Kemampuan guru bahasa Indonesia dapat dilihat dari cara atau proses penyusunan program kegiatan pembelajaran yang dilakukan oleh guru, yaitu perencanaan dalam pengembangan silabus dan rencana pelaksanaan pembelajaran (RPP). Agar Pembelajaran dapat berlangsung secara efektif dan efisien maka perlu adanya program pembelajaran.

Guru mata pelajaran bahasa Indonesia di Sekolah Menengah Pertama Negeri 4 Rejang Lebong telah mengembangkan silabus mata pelajaran bahasa Indonesia dengan mengadopsi silabus yang dikembangkan oleh Balitbang Depdiknas. pengembangan silabus dilakukan oleh para guru dengan baik karena disusun secara berkelompok dalam satu Kecamatan musyawarah guru mata pelajaran (MGMP), dengan disupervisi Tim Pengembang Kurikulum (TPK) Kabupaten yang dibentuk oleh Dinas Pendidikan Nasional Kabupaten.

Langkah-langkah penyusunan silabus yang dilakukan guru telah sesuai dengan peraturan pemerintah Nomor 19 tahun 2005 tentang standar nasional pendidikan bab 5 standar kompetensi kelulusan pasal 25 ayat (3) yang menjelaskan bahwa kompetensi lulusan untuk mata pelajaran bahasa Indonesia menekankan pada kemampuan membaca dan menulis yang sesuai dengan jenjang pendidikan. dalam hal membaca, pada akhir pendidikan di SMP/MTS, peserta didik diharapkan telah membaca.

Guru yang mengajar mata pelajaran bahasa Indonesia pada SMP Negeri 4 Rejang Lebong telah melakukan identifikasi dan meneruskan dan kompetisi-kompetisi yang harus dicapai siswa pada kegiatan belajar mengajar sesuai dengan rumusan standar isi (Standar Kompetensi Dan Kompetensi Dasar). Standar kompetensi adalah kualifikasi kemampuan peserta didik yang menggambarkan penguasaan pengetahuan, sikap, dan 
keterampilan yang diharapkan tercapainya pada mata pelajaran bahasa Indonesia.

Kompetensi dasar merupakan sejumlah kemampuan minimal yang harus dimiliki peserta didik dalam rangka menguasai standar kelulusan mata pelajaran bahasa Indonesia untuk kelas VIII semester 1. Kompetisi dasar dipilih dari yang tercantum dalam standar isi silabus pembelajaran bahasa Indonesia yang disusun oleh guru bahasa Indonesia SMP Negeri 4 Rejang Lebong telah memperlihatkan kriteria pengembangan KBM yang baik. Kriteria yang dimaksud adalah : (a). Kegiatan pembelajaran telah disusun dengan tujuan untuk memberi bantuan kepada guru agar dapat bekerja dan melaksanakan proses pembelajaran secara profesional sesuai dengan tuntutan kurikulum terdapat acuan yang jelas dalam melaksanakan pembelajaran. (b). Kegiatan pembelajaran direncanakan untuk mewujudkan pencapaian kompetensi dasar yang ingin dicapai. (c) kegiatan pembelajaran memuat rangkaian kegiatan yang harus dilakukan oleh siswa secara berurutan untuk mencapai kompetensi dasar. (d) kegiatan pembelajaran berpusat pada siswa (student Centered). Guru merancang kegiatan-kegiatan yang akan dilakukan agar Siswa memiliki kompetensi yang telah ditetapkan. (e) kegiatan pembelajaran dirumuskan dengan jelas namun tidak disertai dalam rumusan materi yang sesuai untuk pencapaian kompetensi dasar. (f) penentuan urutan langkah pembelajaran sangat penting artinya bagi standar kelulusan dan kompetensi dasar yang memerlukan persyaratan tertentu. (g) pembelajaran bersifat spiral (terjadi pengulangan-pengulangan pembelajaran materi tertentu, khususnya untuk pembelajaran membaca. (h) rumusan pernyataan dalam kegiatan pembelajaran minimal mengandung dua unsur penciri yang mencerminkan pengelolaan kegiatan pembelajaran siswa, yaitu kegiatan (siswa dan guru serta objek belajar).

Hasil yang diperoleh atas analisis yang dilakukan terhadap kinerja guru bahasa Indonesia dalam hal manajemen perencanaan pembelajaran di Sekolah Menengah Pertama Negeri 4 Rejang Lebong sudah baik. Ini menunjukkan bahwa perencanaan pembelajaran yang berisikan tujuan pembelajaran, pemilihan materi pembelajaran, metode pembelajaran, urutan langkah-langkah kegiatan pembelajaran, media pembelajaran, sumber pembelajaran, dan penilaian telah dilaksanakan dengan baik. Oleh sebab itu, pelaku yang memiliki tugas dan tanggung jawab penuh terhadap proses belajar mengajar, maka guru dituntut untuk memiliki kemampuan berpikir yang tinggi dalam memahami dan memecahkan masalah-masalah dalam pembelajaran khususnya pembelajaran bahasa Indonesia, Tugas dan tanggung jawab guru bukan hanya sebatas memberi pengetahuan dan penyelesaian materi ajar, tetapi lebih dari itu bahwa guru harus bisa 
manajemen kelas dengan baik dan mempersiapkan peserta didik dengan aktif dan bisa memahami materi dengan baik. Menyusun rencana pelaksanaan pembelajaran (RPP) dalam pembuatan perangkat perencanaan pembelajaran RPP guru guru bahasa Indonesia di SMP Negeri 4 Rejang Lebong melaksanakannya dengan bentuk kelompok pelatihan guru bidang studi bahasa Indonesia melalui kegiatan MGMP. sebelum guru membuat dan menyusun perangkat perencanaan pembelajaran sudah jelas bahwa guru-guru terlebih dahulu harus memahami kurikulum sekolah yang sudah ditetapkan sebagai standar dan dasar penyusunannya.

Skenario pembelajaran yang disusun FZ di atas terlihat sangat kaku dan tidak menciptakan suasana belajar yang menyenangkan. peran guru dalam sekenario tersebut terlibat sangat kaku. Skenario pembelajaran yang dirancang dalam RPP tidak sesuai dengan permainan permainan edukatif cerdas, yang bisa mengkondisikan pembelajaran menjadi menyenangkan dan menumbuhkan minat peserta didik. Dari hasil penelitian terhadap guru bahasa Indonesia di Sekolah Menengah Pertama Negeri 4 Rejang Lebong bahwa visi, misi, dan tujuan pembelajaran bahasa Indonesia belum tertuang secara tertulis. Kurikulum merupakan dasar dari pemahaman guru dalam membuat perangkat pembelajaran, kemudian penguasaan terhadap isi dari setiap pokok bahasan atau materi ajar merupakan syarat muntlak bagi seorang guru untuk menyusun dan melaksanakan manajemen perencanaan pembelajaran.

Hasil wawancara yang dilakukan peneliti terhadap guru bahasa Indonesia di SMP Negeri 4 Rejang Lebong bahwa guru-guru bahasa Indonesia belum memahami dalam membuat perangkat pembelajaran Bahasa Indonesia serta belum menguasai isi dari setiap pokok bahasan atau materi ajar dengan baik. Untuk memahami dan menguasai kurikulum, seorang guru harus memiliki kemampuan yang cukup di dalam menjabarkan tuntutan yang ada di kurikulum.

Menurut Sudjanah dalam Uniah (2008:80) berpendapat bahwa dalam membuat perencanaan pembelajaran, guru harus : (a) menguasai kurikulum, artinya guru harus mempelajari kurikulum, guru harus menguasai tujuan kurikulum, isi program (pokok bahasan), sub pokok bahasan yang harus diberikan kepada siswa pada kelas dan semester mana pokok bahasan itu diberikan (GBPP), dan bagaimana harus memberikannnya, (b) Menguasai setiap pokok bahasan dengan cara mempelajari buku teks yang berkenaan dengan pokok bahasan tersebut, (c) mampu menterjemahkan dan menjabarkan GBPP tersebut menjadi program yang lebih operasional sehingga ia siap mentranspormasikan kepada siswa. 
Dari hasil temuan yang dilakukan peneliti terhadap subjek penelitian berdasarkan indikator yang ada dalam instrumen peneliti, maka dapat peneliti simpulkan bahwa guru-guru Bahasa Indonesia di Sekolah Menengah Pertama Negeri 4 Rejang Lebong belum memiliki visi, misi, dan tujuan dalam pembelajaran bahasa Indonesia secara tertulis dalam penetapan kurikulum sekolah adanya keterlibatan semua warga sekolah, guru-guru bahasa Indonesia telah menyusun program tahunan, program semester, silabus dan rencana pelaksanaan pembelajaran, guru memiliki metode dalam perencanaan pembelajaran, guru melakukan program pengayaan dan remidial terhadap anak didik.

2. Manajemen pelaksanaan pembelajaran bahasa Indonesia

Berdasarkan hasil temuan yang peneliti lakukan terhadap pelaksanaan pembelajaran bahasa Indonesia di Sekolah Menengah Pertama Negeri 4 Rejang Lebong, ditemukan bahwa setiap guru bidang studi bahasa Indonesia melaksanakan pembelajaran dengan baik. Menurut Hamalik (1994:9) bahwa tenaga kependidikan bertugas menyelenggarakan kegiatan belajar, melatih, meneliti, mengembangkan, mengelola, dan memberi layanan teknis dalam bidang pendidikan. Apabila dilihat dari tugasnya mengajar, maka guru harus mempunyai wewenang mengajar berdasarkan kwalifikasinya sebagai tenaga pengajar dan memiliki kemampuan profesional dalam bidang proses belajar mengajar atau pembelajaran. Menurut Roger (dalam, Mujiono,1994:17) mengemukakan langkah-langkah pembelajaran yang dilakukan oleh guru yaitu : (a) Guru memberikan kepercayaan kepada kelas agar kelas memilih belajar secara terstruktur. (b) Guru dan siswa membuat kontrak belajar (c) Guru menggunakan metode inkuiri atau belajar menemukan (d)Guru menggunakan metode simulasi (e) Guru mengadakan latihan kepekaan agar siswa mampu menghayati dengan kelompok lain (f) Guru bertindak sebagai pasilitator belajar (g) Sebaliknya guru menggunakan program agar terciptanya peluang bagi siswa untuk tumbuhnya kreativitas.

Menurut Usman ( 2008:120 ) pelaksanaan pembelajaran mengikuti prosedur memulai pembelajaran, mengelola kegiatan belajar mengajar, mengorganisasikan waktu siswa dan fasilitas belajar, melaksanakan penilaian proses dan hasil belajar dan mengakhiri pelajaran.

Materi ajar atau bahan pelajaran yang ada dalam kurikulum pada hakekatnya merupakanisi kurikulum. Dalam Undang-Undang Pendidikan tentang Sistem Pendidikan Nasional Bab IX, Pasal 39 dinyatakan bahwa "Isi kurikulum merupakan bahan kajian dan pelajaran untuk mencapai tujuan penyelenggaraan suatu pendidikan yang bersangkutan dalam rangka upaya pencapaian tujuan pendidikan nasional" (Depdiknas, 2003). Jadi dalam penentuan kajian bahan atau materi ajar harus dapat disesuaikan 
dengan standar isi kurikulum yang ada. Selanjutnya isi kurikulum harus dapat dikembangkan dan disusun berdasarkan prinsip-prinsip yang ada dalam kajian bahan materi kurikulum. Hamalik (1994:25) mengemukakan tentang prinsip-prinsip pengembangan dan penyusunan materi kurikulum, yaitu (1) Materi kurikulum berupa bahan pelajaran yang terdiri dari bahan kajian atau topik-topik pelajaran yang dapat dikaji oleh siswa dalam proses belajar dan pembelajaran, (2) Materi kurikulum mengacu pada pencapaian tujuan masing-masing satuan pendidikan, dan (3) Materi kurikulum diarahkan untuk mencapai tujuan pendidikan dan tujuan nasional merupakan tujuan yang tertinggi yang hendak dicapai melalui pencapaian materi kurikulum. dari hasil wawancara terhadap guru mata pelajaran bahasa Indonesia di Sekolah Menengah Pertama Negeri 4 Rejang Lebong tentang kesesuaian bahan kajian atau penetapan topik materi pelajaran dengan kompetensi dasar yang telah ditetapkan dalam silabus dapat dinyatakan bahwa semua topik/tema materi ajar yang dilaksanakan dalam proses pelaksanaan pembelajaran sudah sesuai dengan kompetensi dasar yang ada di dalam silabus dan kurikulum sekolah.

Dalam pelaksanaan proses pembelajaran bahasa Indonesia harus juga didukung fasilitas yang memadai sesuai dengan standar sarana dan prasarana yang sudah ditetapkan dalam standar pendidikan nasional. Dari hasil pengamatan dan wawancara yang dilakukan peneliti dapat dinayatakan bahwa dalam pemanfaatan fasilitas pendukung dalam pembelajaran bahasa Indonesia di Sekolah Menengah Pertama Negeri 4 Rejang Lebong belum memiliki fasilitas ruang laboratorium bahasa, dan juga guru tidak bisa menggunakan fasilitas multimedia karena juga belum ada sebagai fasilitas penunjang, seperti TV, DVD, dan lain-lain. Sedangkan dalam pemilihan sumber belajar atau media pelajaran dan melaksanakan di dalam kelas. Media pengajaran yang sering dipakai adalah gambar-gambar yang relevan dengan topik / tema, LKS, koran dan lain-lain. Pemakaian media pembelajaran selain sebagai penunjang dalam proses belajar mengajar, juga berfungsi membantu membangkitkan minat dan motivasi siswa dalam belajar bahasa Indonesia.

Selain guru harus menggunakan media pengajaran dalam proses belajar mengajar, guru harus memiliki metode-metode dalam mengajar. Menurut Hamalik (1994:26) metode adalah cara yang digunakan untuk menyampaikan materi pelajaran dalam upaya mencapai tujuan kurikulum. Metode dalam pembelajaran dilakukan melalui prosedur yang pada dasarnya mengandung pengertian terlaksananya kegiatan guru dan kegiatan siswa dalam prosedur pembelajaran.

Menurut Mukhtar dan Yamin (101-110) metode juga sering disebut dengan strategi yang menempatkan fungsi yang penting dalam kurikulum 
yang memuat tugas-tugas yang perlu dikerjakan oleh siswa dan guru. Klasifikasi metode ceramah, metode demonstrasi, metode diskusi, metode studi mandiri, metode kegiatan pelajar terprogram, metode belajar bersama teman, metode simulasi, metode pemecahan masalah, metode studi kasus, metode bermain peran, metode seminar, metode simposium, metode tutorial, metode deduktif, metode induktif.

Dalam pelaksanaan pembelajaran bahasa Indonesia, ada beberapa indikator yang diteliti. Sebagai bahan acuan peneliti terhadap terlaksananya kegiatan guru dan kegiatan siswa dalam proses pelaksanaan pembelajaran di Sekolah Menengah Pertama Negeri 4 Rejang Lebong. Kegiatan yang dilakukan oleh guru bahasa Indonesia, yaitu tentang penetapan topik materi pokok pembelajaran yang sesuai dengan kompetensi dasar yang ada dalam silabus, pemanfaatan fasilitas pendukung dalam pembelajaran, pemilihan sumber belajar atau media pengajar, metode pembelajaran, dan interaksi dalam proses belajar mengajar.

3. Evaluasi Manajemen Pembelajaran Bahasa Indonesia

Evaluasi pembelajaran bahasa Indonesia merupakan tugas profesional guru bahasa Indonesia dalam menilai keberhasilan proses belajar mengajar. Kegiatan penilaian yang dilakukan oleh guru bahasa Indonesia untuk mengetahui tercapai atau tidaknya sasaran serta tujuan dari materi pembelajaran yang telah diajarkan.

Tahap dari proses pembelajaran adalah evaluasi. Evaluasi merupakan alat ukur tentang tercapai tidaknya tujuan pembelajaran. Menurut Sukardi ( 2008:1) Evaluasi merupakan proses yang menentukan kondisi, dimana suatu tujuan telah dapat dicapai.

Menurut Stufflebeam dalam Rusman (2008:97) evaluasi adalah suatu kegiatan yang menjadi bagian dari manajemen. Oleh karena itu evaluasi bertujuan untuk merumuskan apa yang harus dilakukan, mengumpulkan informasi, dan menyajikan informasi yang berguna bagi penetapan alternatif keputusan.

Menurut Hikmat ( 2009:125 ) mengevaluasi adalah menilai semua kegiatan untuk menemukan indikator yang menyebabkan sukses atau gagalnya pencapaian tujuan, sehingga dapat dijadikan berikutnya.

Menurut Sudiyono ( 2004:32 ) penilaian program bertujuan untuk menyediakan informasi, baik yang bersifat objektif maupun impresionistik yang sangat digunakan untuk bahan pengambilan keputusan.

Dari beberapa pengertian di atas, dapat dipahami bahwa evaluasi hasil belajar peserta didik dilakukan oleh guru yang bertindak selaku pendidik untuk memantau proses, kemajuan, dan perbaikan hasil belajar peserta didik secara berkesinambungan, menyeluruh, transparan dan 
sistematik. Dalam melaksanakan tugas-tugas melakukan penilaian terhadap peserta didik, guru harus memiliki kemampuan mengumpulkan data, menganalisis, menginterprestasikan informasi dan data untuk mengetahui tingkat keberhasilan pelaksanaan pembelajaran, artinya sebelum guru melakukan evaluasi, maka guru terlebih dahulu memahami metodologi penelitian dalam pembelajaran, antara lain pemahaman guru tentang teknik dan alat penilaian, krieteria penilaian yang baik, bentuk-bentuk tes, penskoran, statistik yang berhubungan dengan penilaian, program perbaikan dan pengayaan. Guru harus memiliki kemampuan dalam pengukuran baik terhadap proses maupun hasil pembelajaran, kemampuan guru dalam melakukan kodifikasi dan penskoran, kemampuan guru dalam memberikan balikan, dan kemampuan guru dalam melaksanakan program perbaikan proses belajar mengajar serta pengayaan terhadap siswa yang belum tuntas dalam memahami materi ajar, melaksanakan ujian tengah semester, melaksanakan ujian akhir semester, ujian praktik, ujian nasional. Dan guru bahasa Indonesia juga mengadakan program remedial dan pengayaan terhadap siswa. Ulangan harian dilaksanakan berdasarkan kompetensi dasar, yaitu setelah menyelesaikan materi pelajaran sebanyak dua komponen dasar. Penilaian tugas dilaksanakan per pokok bahasan. Ujian praktik dilaksanakan berdasarkan kompetensi menulis. Ujian semester dibuat guru bahasa Indonesia di sekolah tersebut dan ujian nasional dilaksanakan di sekolah sendiri. Pelaksanaan analisis tes formatif dilaksanakan setelah ulangan harian.

Menurut Jutmini dkk (2007:1) tujuan evaluasi belajar adalah untuk membedakan kegagalan dan keberhasilan seseorang peserta didik. Namun dalam pengembangannya evaluasi dimaksudkan untuk memberikan umpan balik kepada peserta didik maupun kepada pembelajar sebagai pertimbangan untuk melakukan perbaikan serta jaminan terhadap pengguna lulusan sebagai tanggung jawab institusi yang telah meluluskan.

Menurut Suharsimi Arikunto (2013:67) tes adalah merupakan alat atau prosedur yang digunakan untuk mengetahui atau cara untuk mengukur sesuatu dalam suasana, dengan cara dan aturan yang sudah di tentukan.

Menurut S.Eko Putro Widoyoko ( 2010:45 ) tes merupakan salah satu alat untuk melakukan pengukuran, yaitu alat untuk mengumpulkan informasi karaktristik suatu objek.

Ada beberapa teknik dan alat penilaian yang dapat digunakan sebagai sarana untuk memperoleh informasi tentang keadaan belajar peserta didik. Teknik penilaian yang memungkinkan dapat dengan mudah 
digunakan antara lain menurut Safari (2004:4) adalah : tes (baik tes tertulis, lisan, dan perbuatan), observasi atau pengamatan, dan wawancara.

Dalam tes tertulis, soal harus dijawab oleh peserta didik dengan memberikan jawaban secara tertulis. Jenis tes ini secara umum dapat dikelompokkan menjadi dua, yaitu Pertama, tes objektif misalnya bentuk pilihan ganda, isian atau jawaban singkat, benar atau salah dan bentuk menjodohkan; Kedua, tes uraian yang terbagi atas tes uraian objektif dan tes uraian non objektif.

Evaluasi pembelajaran biasa dilakukan di sekolah antara lain ulangan harian, ulangan tengah semester, dan ulangan semester. Ulangan harian dimaksudkan untuk mengukur kemampuan peserta didk atas materi yang telah disampaikan setiap kompetensi dasar. Ulangan tengah semester dimaksudkan untuk mengetahui kemampuan peserta didik memahami materi yang dilakukan selama setengah semester, sedangkan ulangan semester dilakukan untuk mengukur keterpahaman materi yang telah disampaikan oleh guru selama kurun waktu satu semester.

Bagi peserta didik yang belum mencapai ketuntasan biasanya sekolah mengadakan program remidial yaitu program pembelajaran tambahan untuk membantu peserta didik memahami materi-materi yang belum dikuasainya sehingga ia mencapai tingkat ketuntasan yang diinginkan. Sebaliknya, sekolah juga mengadakan program pengayaan bagi peserta didik yang telah mencapai ketuntasan lebih awal, sehingga ia tidak menyia-nyiakan waktu yang tersedia.

Dari hasil penelitian di atas diperoleh bahwa Sekolah Menengah Pertama Negeri 4 Rejang lebong telah melaksanakan program penilaian pembelajaran sesuai dengan ketentuan-ketentuan yang berlaku. Guru bahasa Indonesia telah melaksanakan evaluasi pembelajaran sampai proses analisis soal untuk mendapatkan soal yang valid.

Menurut Muslich (2007:92) hal-hal yang harus diperhatikan oleh guru dalam melaksanakan penilaian berbasis kelas yaitu : Pertama, memandang penilaian sebagai bagian integral dari kegiatan pembelajaran, Kedua, mengembangkan strategi pembelajaran yang mendorong dan memperkuat proses penilaian sebagai kegiatan refleksi, Ketiga, melakukan berbagai strategi penilaian dan pembelajaran, dan keempat, mengembangkan sistem pencatatan dengan cara-cara yang bervariasi.

4. Inovasi yang dilakukan dalam manajemen pembelajaran bahasa Indonesia

Kemampuan guru bahasa Indonesia dapat dilihat dari cara atau proses penyusunan program kegiatan pembelajaran yang dilakukan oleh guru, yaitu perencanaan dalam mengembangkan silabus dan rencana pelaksanaan pembelajaran (RPP). Agar pembelajaran dapat berlangsung secara efektif dan efisien maka perlu adanya program pembelajaran. 
Menurut Hamalik (2001:136) Setiap perencanaan memiliki kriteria sendiri yang secara umum dirangkumkan dalam perangkat pembelajaran yang harus dimiliki seorang guru.

Hasil yang diperoleh atas analisis yang dilakukan terhadap kinerja guru bahasa Indonesia dalam hal perencanaan pembelajaran di SMP Negeri 4 Rejang Lebong sudah baik. Ini menunjukkan bahwa perencanaan pembelajaran yang berisikan tujuan pembelajaran, pemilihan materi pembelajaran, metode pembelajaran, langkah-langkah kegiatan pembelajaran, media pembelajaran, sumber pembelajaran, dan penilaian dilaksanakan dengan baik.

Inovasi yang dibuat oleh Sekolah Menengah Pertama Negeri 4 Rejang Lebong dalam perencanaan pembelajaran secara umum adalah merumuskan silabus, menentukan KKM, menyiapkan format pembelajaran, penyusunan perangkat pembelajaran, dan penyusunan RPP. Pelajaran merupakan salah satu bentuk program karena pembelajaran yang baik memerlukan perencanaan yang matang dan dalam pelaksanaannya melibatkan banyak orang, baik guru maupun peserta didik memiliki keterkaitan antara kegiataan pembelajaran yang satu dengan yang lainya yaitu mencapai kompetisi yang dituntut oleh mata pelajaran yang bersangkutan. Agar pelajaran dapat berlangsung secara efektif dan evesien maka perlu adanya program pembelajaran.

Inovasi yang dilakukan dalam pembelajaran di Sekolah Menengah Pertama Negeri 4 Rejang Lebong adalah : adanya inovasi dalam fokus kegiatan pembelajaran, cara menyusun perangkat pembelajaran, peran guru dalam pembelajaran, pemilihan dan penentuan metode/media pembelajaran, acuan guru dalam pembelajaran, suasana pembelajaran, tempat pembelajaran. Sama halnya dengan perencanaan pembelajaran, tahap pelaksanaan pembelajaran pun tetap memperhitungkan keempat aspek keterampilan berbahasa, yaitu : mendengarkan, berbicara, membaca dan menulis. Mengingat keempat keterampilan ini sama pentingnya. Maka pelaksanaanya pun harus berimbang.

Dahulu guru menyusun perangkat pembelajaran secara sendirisendiri, maka sekarang mereka melakukan penyusunan pembelajaran secara bersama-sama yang dilakukan penyusunan pembelajaran secara bersama-sama yang dilakukan di awal semester. Dalam hal ini seolah tidak membakukan format yang digunakan dalam penyusunan perangkat sebagaimana yang dilakukan di Sekolah menengah Pertama Negeri 4 Rejang Lebong. Jadi format RPP masih berpedoman pada format yang dikeluarkan oleh BNSNP, setelah di inovasi format RPP sudah disusun bersama MGMP bahasa Indonesia di wilayah kecamatan. 
Hal ini juga dibenarkan oleh guru bahasa Indonesia di Sekolah Menengah Pertama Negeri 4 Rejang Lebong, FZ. Penyusun ini perlu dilakukan karena setiap sekolah mempunyai perbedaan di lingkungan sekolah, peserta didik, guru, fasilitas, dan sebagainya. Penentuan kriteria ketuntasan minimal juga sudah disusun berdasarkan daya dukung dan kompleksitas.

\section{Kesimpulan}

Berdasarkan hasil temuan dan pembahasan bahwa manajemen dan mutu pembelajaran bahasa Indonesia di Sekolah Menengah Pertama Negeri 4 Rejang Lebong, baik perencanaan program, pelaksanaan program, evaluasi program, dan inovasinya sudah dilaksanakan serta di motivasi oleh sekolah kesimpulannya:

1. Dalam perencanaan manajemen mutu pembelajaran bahasa Indonesia di Sekolah Menengah Pertama Negeri 4 Rejang Lebong, untuk program tahunan dan program semester telah di susun secara bersama-sama melalui musawarah guru mata pelajaran. Program tahunan dan program semester di susun berdasarkan kalender pendidikan, penyusunan silabus dan RPP di susun bersama-sama guru mata pelajaran bahasa Indonesia melalui musyawarah guru mata pelajaran tingkat satuan pendidikan.

2. Dalam pelaksanaan manajemen mutu pembelajaran bahasa Indonesia di Sekolah Menengah Pertama Negeri 4 Rejang Lebong, telah melaksanakan proses pembelajaran di mulai dengan memberikan salam sewaktu masuk ruangan kelas, mengabsen siswa dan membuka pelajaran serta menetapkan topik sesuai dengan bahan ajar, sesuai dengan kompetensi dasar dan silabus, juga sesuai dengan alokasi waktu yang ada dalam RPP dan terakhir menutup pelajaran dan menyimpulkan materi pelajaran.

3. Dalam evaluasi manajemen pembelajaran bahasa Indonesia di Sekolah Menengah Pertama Negeri 4 Rejang Lebong, telah melaksanakan ulangan harian, ulangan tengah semester, ulangan akhir semester, ujian praktik dan ujian nasional dan memberikan tugas kepada siswa.

4. Dalam inovasi manajemen pembelajaran bahasa Indonesia merumuskan silabus, perangkat pembelajaran, menyusun RPP. Sedangkan inovasi yang dilaksanakan dalam pembelajaran adalah pemilihan metode, buku pegangan guru dalam pembelajaran, tempat pembelajaran. Inovasi dalam bentuk evaluasi adalah sasaran penilaian, penentuan KKM, persiapan soal, jadwal penilaian dan analisis hasil penilaian.

\section{Daftar Pustaka}

Arikunto, 1998. Pengelolaan dan Siswa. Jakarta: CV rajawali

Arikunto, Suharsimi. 2013. Dasar-dasar Evaluasi Pendidikan, Jakarta: Bumi Aksara. 
Arikunto, Suharsini. 2002. Prosedur Suatu Pendekatan Praktik. Jakarta: Penerbit Rineka Cipta.

Baryadi, Praptomo. 2000. Dasar-dasar Analisis Wacana Dalam Ilmu Bahasa, Yogyakarta: Pustaka Ghondosuli.

Bruner, J.S. 1960. The Process Of Education. Combbridge: Harvard University Press.

Chaer, Abdul, 2011. Psykolinguistik, kajian Teoritik, Cetakan Kedua, Jakarta : Renika Cipta.

Efendi Anwar, 2008. Bahasa dan Sastra Dalam Berbagai Perspektif, Yogyakarta; Tiara Wacana

Hamalik, U. 2001. Kurikulum dan Pembelajaran. Jakarta; Bumi Angkasa. Cetakan Pertama.

Hendry Guntur Tarigan, 1985. Pengajaran Gaya Bahasa, Bandung; Angkasa

Hendry Guntur Tarigan, 1988. Metodologi Pengajaran Bahasa, Bandung; Angkasa

Hendry Guntur Tarigan, 2009. Pengajaran Wacana, Bandung; Angkasa

Hikmat, 2011. Manajemen Pendidikan, Bandung; CV.Pustaka Setia, Cetakan kedua

Khaeruddin, dan Mahfud Junaidi,2007. Kurikulum Tingkat Satuan Pendidikan: Konsep dan Implementasi di Madrasah. Yogyakarta : Pilar Media.

Lubis, Hamid Hasan.1993. Analisis wacana Pragmatik. Bandung: Angkasa.

Majid, Abdul, 2013 Perencanaan Pembelajaran Standar kompetensi Guru, Cetakan Kesepuluh, Bandung : Rosda.

Nasution S. 1989, Pengembangan Kurikulum. Bandung: Citra Aditya Bakti.

Nasution S. 1996, Meode Penellitian Naturalistic Kualittif. Bandung: Tarsito.

Nazarudin, 2007, Manajemen Pembelajaran,Yogyakarta: Teras

P.C. Tripathi dan P.N. Reddy. 2008. Principles of Management New Delhi :

Tata MCGraw-Hill Publishing Company Limited.

Padeta, Mansoer. 2001, Simantik Leksikal, Rineka Cipta, Edisi Kedua

Pateda, Mansoer. 1991, Linguistik Terapan. Flores: Nusa Indah.

Robrt D Gatewood, Robert R. taylor dan O.C. Ferrel, 1995. Management. Chicago : Richard D. Irwin, Homewood II

Rusman, 2008, Manajemen Kurikulum, Bandung: Rajawali Pers

Sudarwan Danim.2007.Visi Baru Manajemen Sekolah. Jakarta : Bumi Aksara

Sudiyono, 2004. Manajemen Pendidikan Tinggi, Jakarta; PT.Rineka Cipta,

Sudjana, Nana, 2004. Hasil proses Belajar Mengajar. Bandung: Rosdakarya.

Sukardi, 2008. Evaluasi Pendidikan Perinsip dan Oprasionalnya. Jakarta:

Bumi Aksara.

Usman, Husaini, 2008.Manajemen Teori, Praktek, dan Riset Pendidikan, Edisi Kedua, Jakarta : PT. Bumi Aksara. 
Widoyoko.S. Putro Eko, 2010, Evaluasi Program Pembelajaran, Yogyakarta: Pustaka Pelajar 
88 | TADBIR : Jurnal Studi Manajemen Pendidikan, Vol. 2, No. 1, 2018

This page belongs to the TADBIR : Jurnal Studi Manajemen Pendidikan TADBIR : Jurnal Studi Manajemen Pendidikan vol. 2 , no. 1, 2018

STAIN Curup - Bengkulu | p-ISSN 2580-3581; e-ISSN 2580-5037 